\title{
Drying kinetics and optimization for thin-layer drying processes of raspberries (Rubus coreanus Miq.) using statistical models and response surface methodology
}

\author{
Hui Teng ${ }^{1}$, Won Young Lee ${ }^{1,2 *}$ \\ ${ }^{1}$ Food and Bio-Industry Research Institute, Kyungpook National University, Daegu 702-701, Korea \\ ${ }^{2}$ School of Food Science and Bio-Technology, Kyungpook National University, Daegu 702-701, Korea
}

\section{통계적 모델과 반응표면분석을 이용한 복분자의 건조조건 최적화 및 건조거동}

\author{
텅 후이 ${ }^{1} \cdot$ 이원영 $1,2 *$ \\ ${ }^{1}$ 경북대학교 식품생물산업연구소, ${ }^{2}$ 경북대학교 식품공학부
}

\begin{abstract}
Raspbemies are a good resource of polyphenols and have a powerful antioxidant activity, but shelf life for raspbenies is short which brings a lot of economic losses. In this study, we try to use cool-air $\left(20 \sim 40^{\circ} \mathrm{C}\right)$ or hot-air $\left(60 \sim 100^{\circ} \mathrm{C}\right)$ to produce semi-dried raspberries with extended shelf life, and to determine the best method for improving fruit quality by minimizing nutrient losses during drying processes. The effects of process variables (drying temperature and processing time) on the quality of final dried raspberries were investigated. Response surface methodology was employed to establish statistical models for simulating the drying processes, and the moisture residue content and the loss ratios of total phenolic content (TPC), vitamin C (VC), and ellagic acid (EA) that result from the drying processes of raspberries using either hot or cool-air were predicted. Superimposed contour plots have been successfully used in the determination of the optimum zone within the experimental region. Optimal conditions determined for achieving minimal losses of TPC, VC, and EA, and a final moisture residue of $45 \%$ using the hot-air drying process were a drying temperature of $65.75^{\circ} \mathrm{C}$ and a processing time of $4.3 \mathrm{hr}$. While for the cool-air process, the optimal conditions predicted were $21.3^{\circ} \mathrm{C}$ and $28.2 \mathrm{hr}$. Successful application of response surface methodology provided scientific reference for optimal conditions of semi-drying raspberries, minimizing nutrient losses and improving product quality.
\end{abstract}

Key words : raspberry, response surface methodology, semi-dry, optimization

\section{Introduction}

Raspberries, which belong to the family Rosaceae, have a high economic value as fruiting species and are widely distributed in Southeast Asian countries (1). Recent studies (2-4) have found that raspberries contain an abundant amount

*Corresponding author. E-mail : wonyoung@knu.ac.kr Phone : 82-53-950-7763, Fax : 82-53-950-7762

Received 10 November 2014; Revised 8 January 2015; Accepted 14 January 2015.

Copyright (c) The Korean Society of Food Preservation. All rights reserved. of polyphenols (278 to $714 \mathrm{mg}$ gallic acid equivalents/100 $\mathrm{g}$ ), anthocyanins (325 mg cyanidin 3-glucoside equivalents $/ 100 \mathrm{~g})$, and vitamin C $(9.2 \mathrm{mg} / 100 \mathrm{~g})$. Further, daily raspberry intake has been shown to confer protective effects against several degenerative diseases (5). Unfortunately, raspberries are highly perishable as they readily rot when infected by gray mold (Botrytis cinerea), resulting in a loss of firmness and a darkening of their attractive red color (6). In order to retain fruit quality during long-term storage, most raspberries are currently preserved in frozen form after harvest. However, frozen raspberries result in a significant dripping loss once they are thawed, and the inevitable loss 
of flavors and nutritional value (7). Therefore, other processing techniques are required for developing nutritional raspberry products.

Drying is the most common and effective method for food preservation and shelf-life extension (8). The drying process leads to a reduction of the moisture content to a satisfactory level, allowing safe storage over an extended period. In addition, for small fruits like raspberries and mulberries, it also results in a substantial water loss, increasing sweetness and flavor. Compared to other processed raspberry products such as juice, candy, and syrup, dried raspberries do not contain any harmful additives (such as antiseptics, colorants, or aromatic chemicals), making them more natural, healthier, and popular with consumers. Solar drying is a widely used process to preserve foods, but problems associated with solar drying are well documented (9). Alternatively, dehydration in air driers at controlled temperatures and air flow ensures the establishment of the appropriate moisture level and better preservation of product quality. At present, dehydration using hot-air $\left(60 \sim 100^{\circ} \mathrm{C}\right)$ is common for various fruits and vegetables $(10,11)$. However, the product quality and flavor resulting from hot-air drying are often reduced due to excessive temperature and drying time. More importantly, reduction of the moisture content to a low level can result in food that is too difficult to eat for some consumers, such as children and the elderly. Therefore, researchers are currently focused on developing semi-dried foods such as spices (pepper), fruits (persimmons and tomatoes), and meats (pork and beef) with softer tastes, retained nutrient values and antioxidant activities, as well as extended shelf-lifes (12-15). Increasing demand for high quality and nonperishable dried fruit requires the optimization of the dehydration process, especially with regards to drying temperature and processing time. Such optimization may critically affect not only the efficiency of the drying process, but also the quality of the final dehydrated product (16).

In pursuit of this optimization, this study applied hot-air drying $\left(60 \sim 100^{\circ} \mathrm{C}\right)$ and cool-air drying $\left(20 \sim 40^{\circ} \mathrm{C}\right)$ under vacuum to produce semi-dried raspberries. The aim of the present research was to investigate the influence of drying temperature and processing time on the quality of semi-dried raspberries, and to predict optimal drying conditions so as to minimize nutrient losses during the drying process by developing statistical models according to response surface methodology (RSM). The total loss of vitamin C (VC), total phenolic content (TPC), and ellagic acid (EA) were used to evaluate the quality of the final raspberry product.

\section{Material and methods}

\section{Raspberry sample}

Raspberries (Rubus coreanus Miq.) were obtained from the city of Mungyeong in the Gyeongbuk area of Korea, and were harvested by hand and kept refrigerated at $4^{\circ} \mathrm{C}$ before drying. The moisture content of the fresh and dried mulberry fruits were determined by AOAC method no. 934.06 (AOAC, 1990).

\section{Drying of fresh raspberries}

Hot-air drying was conducted in a lab-scale convective air dryer $\left(0 \sim 2 \mathrm{~m} / \mathrm{s}, 10 \sim 120^{\circ} \mathrm{C}\right)$. The temperature was set constant between 60 and $100^{\circ} \mathrm{C}$ using a temperature controller. Cool-air drying was carried out in a forced circulation and batch type (Shinil, Seoul, Korea). This device allowed for temperature ranges between 20 and $40^{\circ} \mathrm{C}$, with $1.0^{\circ} \mathrm{C}$ variation. The air velocity was fixed at $1 \mathrm{~m} / \mathrm{s}$. For both drying processes, approximately $100 \mathrm{~g}$ of the fresh harvested raspberries were weighed, put on an aluminum plate, and placed in the respective drying devices. After drying, the moisture residue content was recorded and the dried raspberries were preserved in a zipper bag at $-20^{\circ} \mathrm{C}$ until further extraction and chemical analysis.

\section{Extraction of semi-dried raspberries}

A $5 \mathrm{~g}$ of semi-dried raspberries were collected in a centrifuge tube $(50 \mathrm{~mL})$ and macerated with $25 \mathrm{~mL}$ acidified methanol $(0.1 \% \mathrm{HCl})$ for $10 \mathrm{~min}$. The macerated raspberries were then homogenized using a Polytron PT1200 homogenizer (Kinematika, Littau, Switzerland) and ultrasonicated for 30 min in a laboratory ultrasonic bath (JAC Ultrasonic 2010P, Jinwoo Engineering Co., Ltd., Hwasung, Korea). Afterwards, the treated homogenate was centrifuged at $2,000 \times \mathrm{g}$ for 20 min at $4^{\circ} \mathrm{C}$ and the supernatant was collected in a brown vial. A $2 \mathrm{~mL}$ extract was injected through a $0.45 \mu \mathrm{m}$ PTFE syringe filter for analysis of TPC, VC, and EA content.

\section{Total phenolic content determination}

The TPC was determined using the Folin-Denis method described by Singleton et al. (17) with modifications. A 100 $\mu \mathrm{L}$ of previously filtered raspberry supernatant was mixed with $50 \mu \mathrm{L}$ of Folin-Ciocalteu reagent and $300 \mu \mathrm{L}$ of $2 \%$ $\mathrm{Na}_{2} \mathrm{CO}_{3}$. After keeping at room temperature for $15 \mathrm{~min}, 1$ $\mathrm{mL}$ of distilled water was added and the absorbance was measured at $725 \mathrm{~nm}$. The results were expressed as a percentage (\%) of loss ratio as compared to the untreated 
raspberry sample (dry basis).

\section{Vitamin C determination}

Vitamin C content was analyzed using HPLC (JASCO International Co., Tokyo, Japan) with an XTerra C18 reversed-phase column $(250 \mathrm{~mm} \times 4.6 \mathrm{~mm}$, Waters, USA), according to the method described by Phillips et al. (18) with minor modifications. The mobile phase consisted of $0.15 \%$ aqueous formic acid. A $60 \mu \mathrm{L}$ of previously filtered raspberry supernatant was injected into the HPLC system and eluted under isocratic conditions at $1 \mathrm{~mL} / \mathrm{min}$. Absorption was

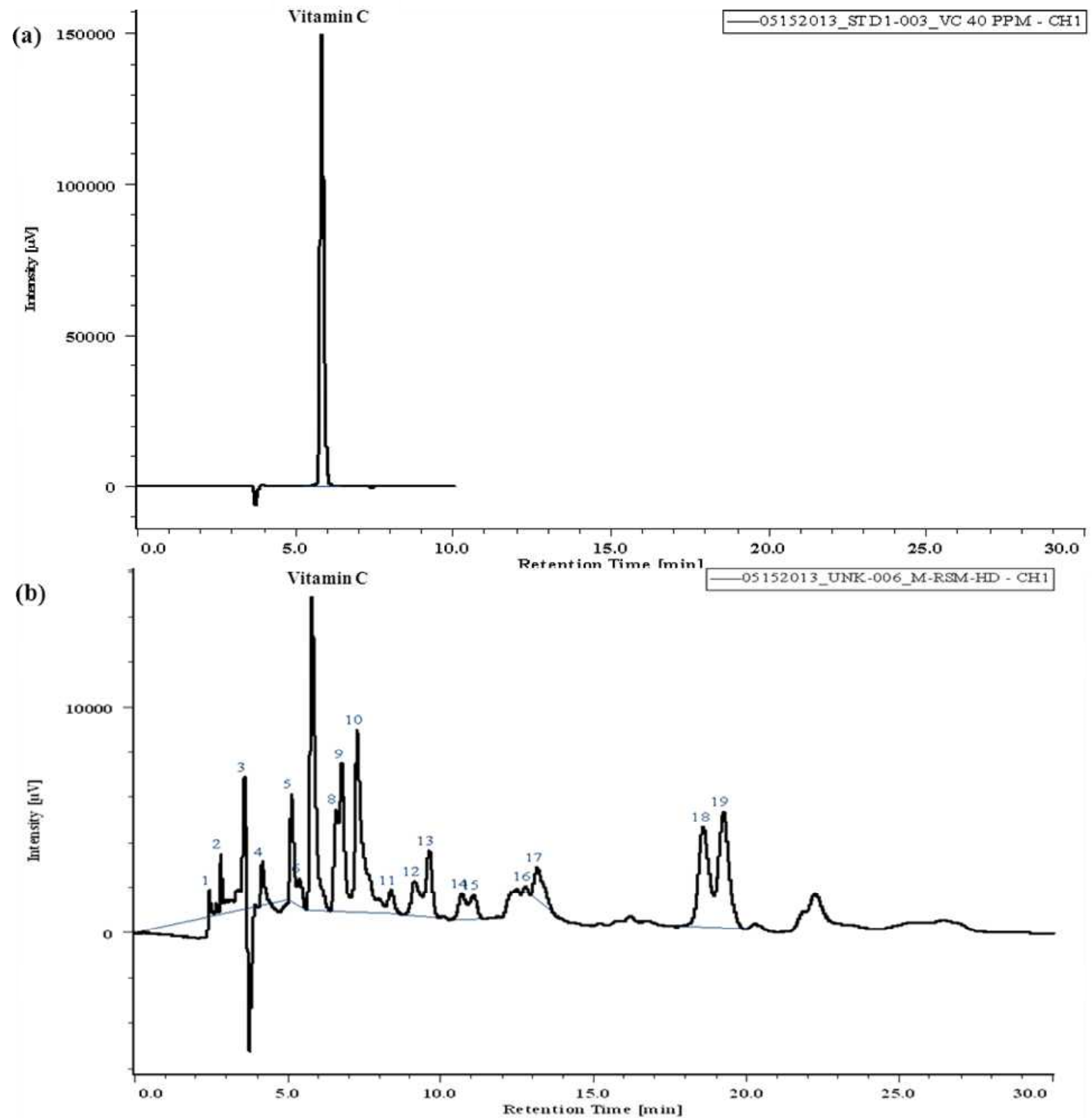

detected at $255 \mathrm{~nm}$ with a UV detector. Ascorbic acid (10 30 $\mu \mathrm{g} / \mathrm{mL}$ ) was used as an external standard and Fig. 1(a) shows the peak of ascorbic acid eluted at $6.8 \mathrm{~min}$. Under these conditions, vitamin $\mathrm{C}$ content in dried raspberries got fully separated as shown in Fig.1(b). The results were expressed as a percentage (\%) of loss ratio as compared to the untreated raspberry sample (dry basis).

\section{Ellagic acid determination}

Ellagic acid was separated and identified using HPLC (JASCO International Co., Tokyo, Japan) with a UV detector.

Fig. 1. HPLC profiles for vitamin C from raspberries. 
Separation was performed on an XTerra C18 reverse phase column $(250 \mathrm{~mm} \times 4.6 \mathrm{~mm}$, Waters, USA $)$ at $30^{\circ} \mathrm{C}$. The mobile phase consisted of 5\% aqueous acetic acid (in water) and $0.1 \%$ formic acid (in acetonitrile solution). A $60 \mu \mathrm{L}$ of the previously filtered raspberry supernatant was injected, and a flow rate of $0.8 \mathrm{~mL} / \mathrm{min}$ was used. Absorption was detected at $280 \mathrm{~nm}$ and retention time was $60 \mathrm{~min}$. Ellagic acid ((10-50 $\mu \mathrm{g} / \mathrm{mL}$ ) was employed as an external standard and eluted at $24.8 \mathrm{~min}$ as shown in Fig. 2(a). Under these conditions, individual peaks shown in Fig. 2(b) suggested a good separation of chemical compounds in dried raspberries. The results were expressed as a percentage (\%) of loss ratio as compared to the untreated raspberry sample (dry basis).

\section{Experimental design}

A central composite design (CCD) generated by SAS software (9.3, SAS Institute, Cary, NC, USA) was employed for the optimization of the drying process. The drying temperature and processing time for the hot-air drying process were $60 \sim 100^{\circ} \mathrm{C}$ and $2 \sim 10 \mathrm{hr}$, respectively. For the cool-air

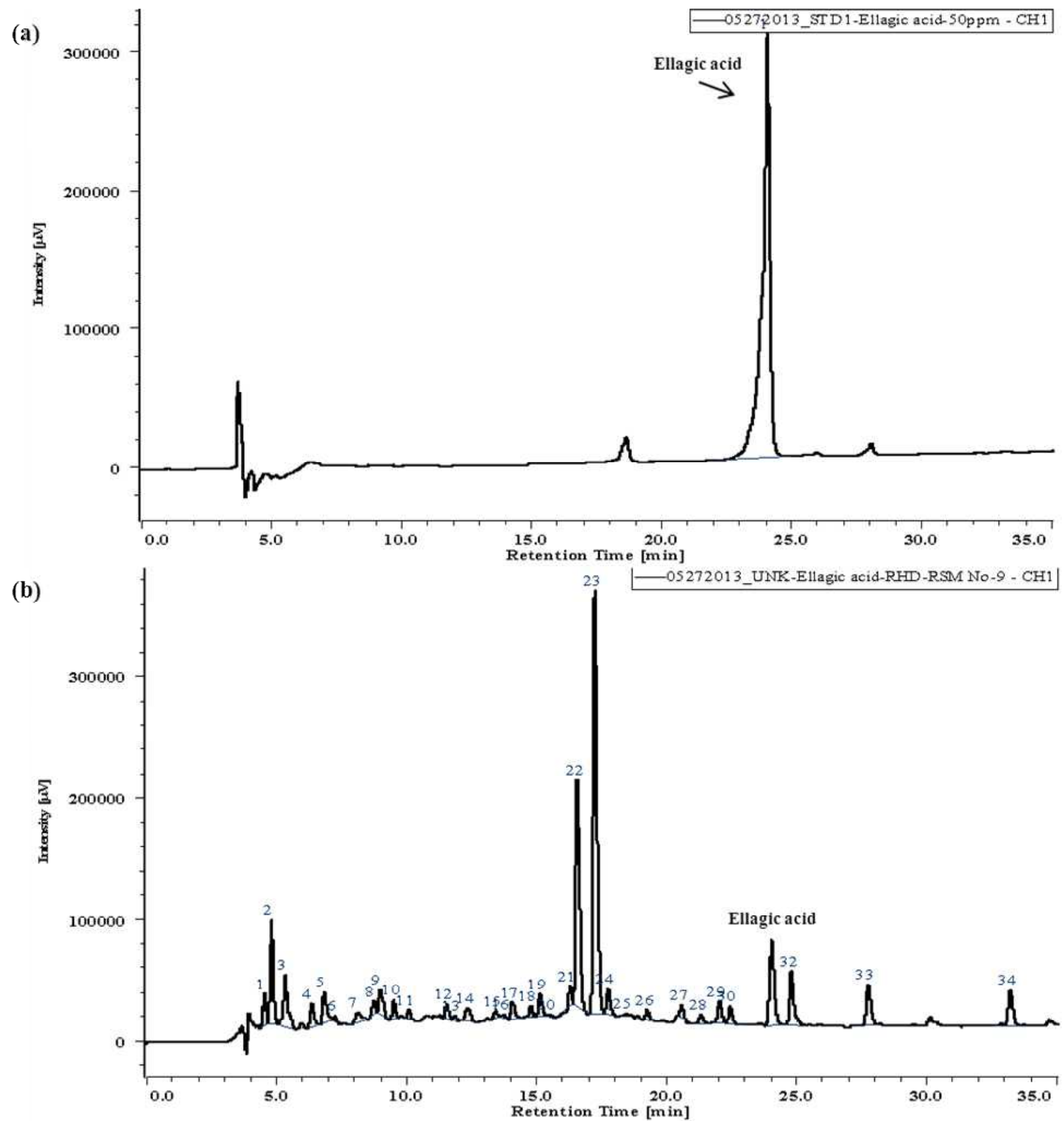

Fig. 2. HPLC profiles for ellagic acid from raspberries. 
drying process, these values were $20 \sim 40^{\circ} \mathrm{C}$ and $22 \sim 66 \mathrm{hr}$, respectively. Experimental data were fitted into an empirical second order polynomial model using regression analysis and presented in the following equation:

$$
Y=\beta_{0}+\sum_{i=2}^{k} \beta_{i} \chi_{i}+\sum_{i=2}^{k} \beta_{i i} \chi_{i}^{2}+\sum_{1 \leq i \leq j}^{k} \beta_{i j} \chi_{i} \chi_{j}+\epsilon
$$

In the equation above, $\mathrm{Y}$ represents the independent responses, $\beta_{0}, \beta_{\mathrm{i}}, \beta_{\mathrm{ii}}$, and $\beta_{\mathrm{ij}}$ represent the regression coefficients of the process variables for the intercept, linear, quadratic, and cross product terms, respectively, and $\varepsilon$ represents the error. Statistical significance of the coefficients in the regression equation was checked by analysis of variance (ANOVA). The fit of the polynomial model equation to the responses was evaluated using both the R-squared $\left(\mathrm{R}^{2}\right)$ coefficient and the F-test.

\section{Statistical analysis}

Statistical analyses, including analysis of variance (ANOVA), fit statistics, and canonical analysis, were completed using
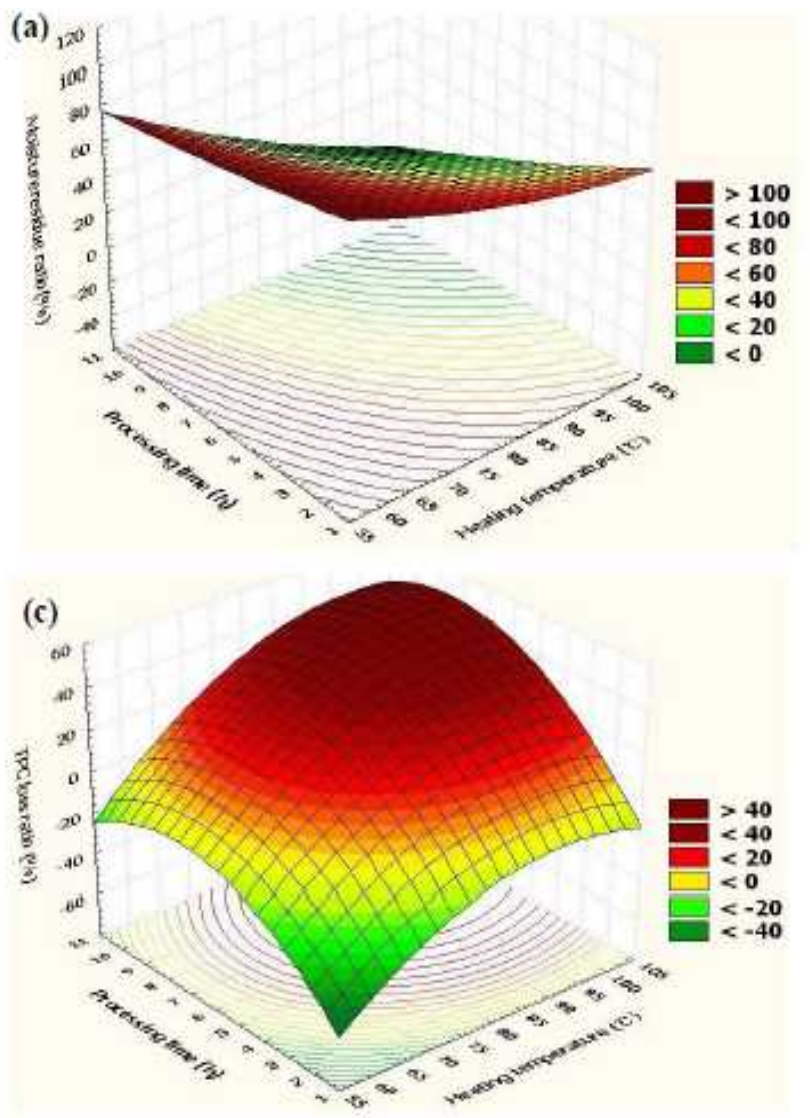

SAS software (9.3, SAS Institute, Cary, NC, USA). Three-dimensional response surface plots and overlapped contour plots were generated using STATISTICA 8.0 (Statsoft Inc., NY, USA).

\section{Results and discussion}

When analyzing food, ascorbic acid is usually taken as an important index of nutrient quality. It is a labile compound that may lose activity due to several factors, including $\mathrm{pH}$, moisture content, oxygen, temperature, and metal ion catalysis $(19,20)$. According to Puupponen-Pimiä et al. (21), raspberries contain relatively high amounts of bioactive compounds (flavonoids, phenolic acids, and tannins). Ellagic acid is the main phenolic compound in both fresh and dried raspberries, forming $77-88 \%$ of the phenolic compounds analyzed, which is affected by many different factors during food processing and storage, including light, temperature, and humidity (22-24).

In this study, conventional hot-air and cool-air were

(b)

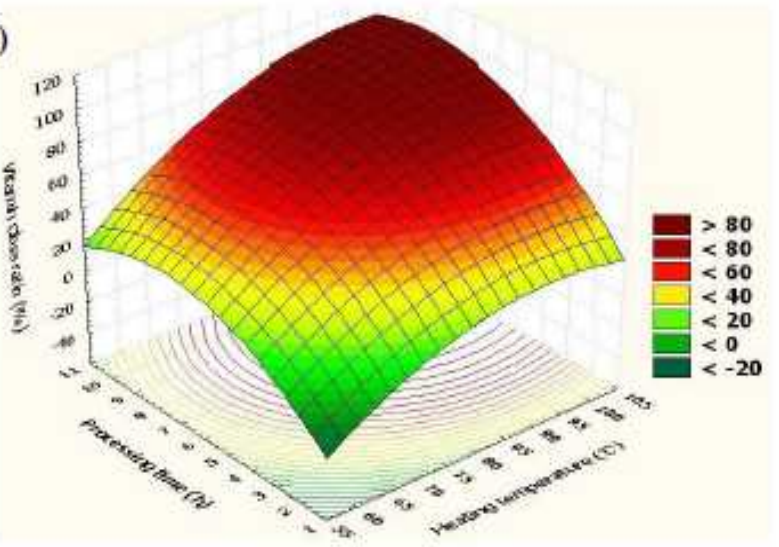

(d)

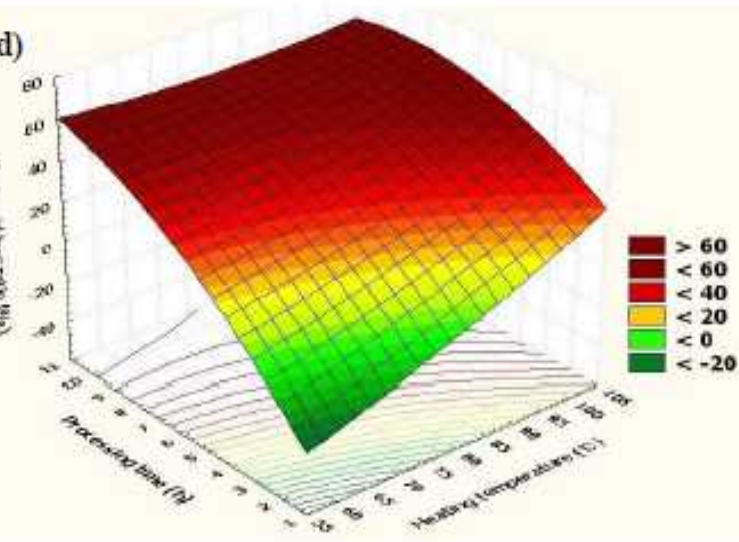

Fig. 3. Three-dimensional surface plots for semi-drying raspberries under hot-air conditions.

(a), moisture residue ratio (MRR); (b), vitamin C loss ratio (VCLR); (c), TPC loss ratio (TPCLR); (d), ellagic acid loss ratio (EALR). 
(a)
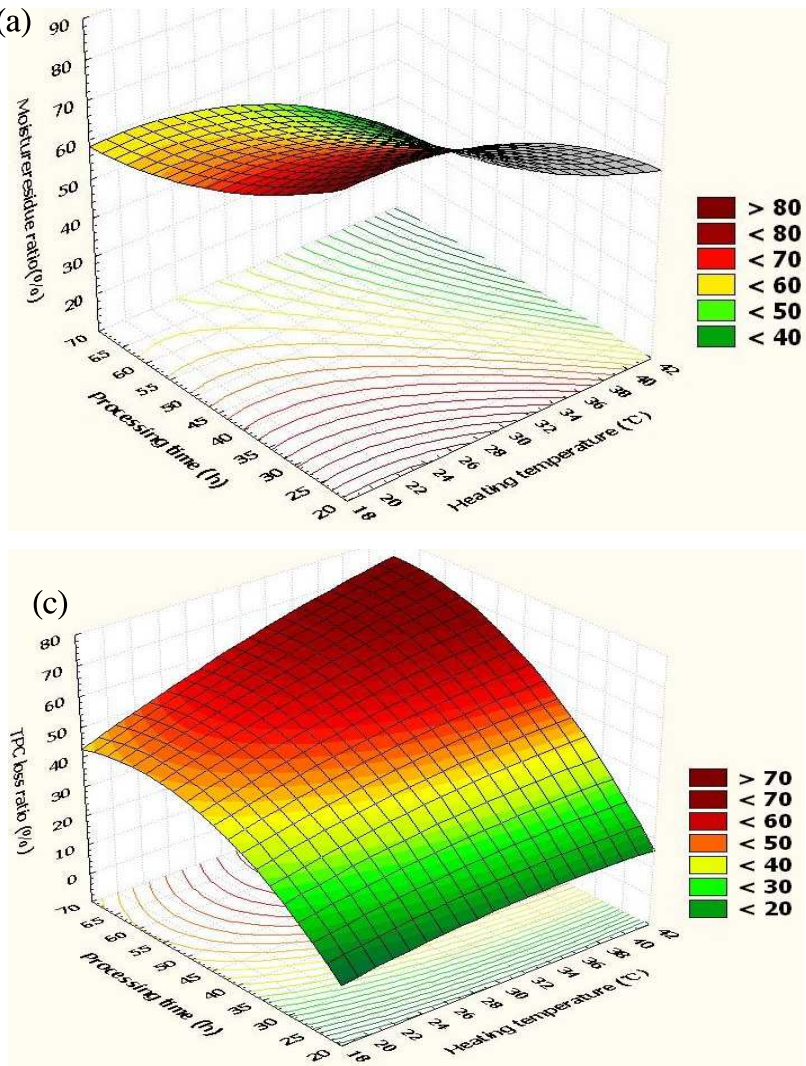
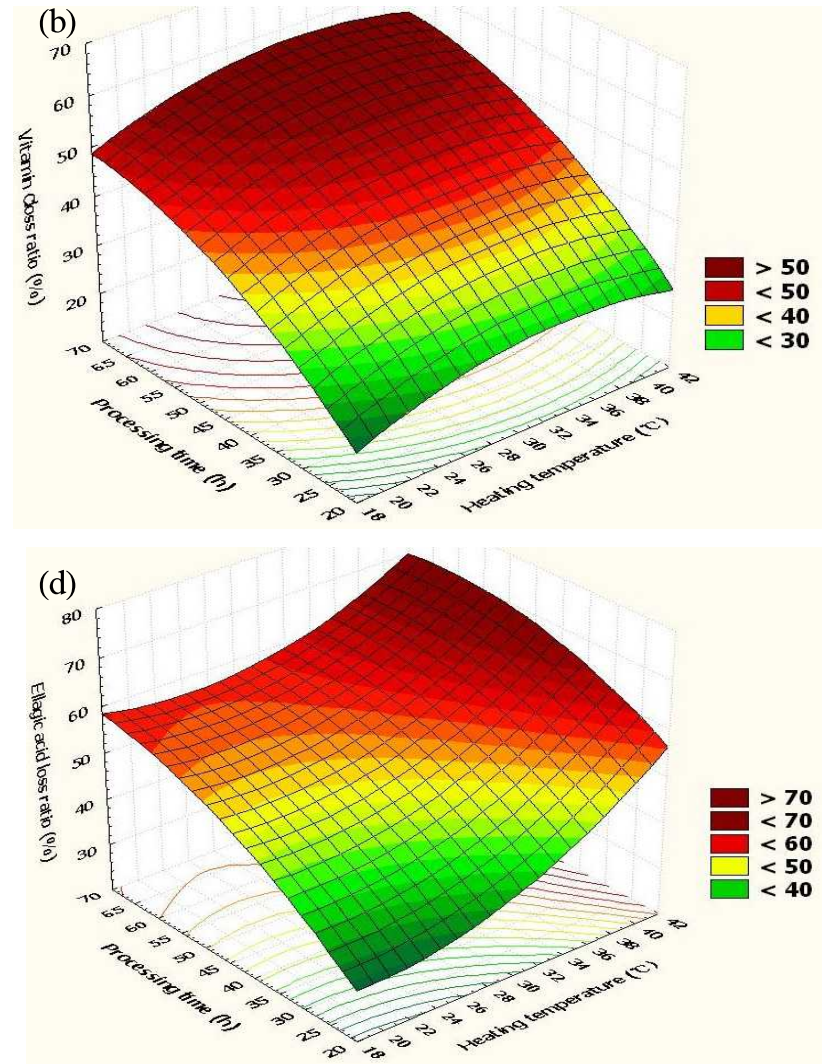

Fig. 4. Three-dimensional surface plots for semi-drying raspberries under cool-air conditions and vacuum. (a), moisture residue content (MRR); (b), vitamin C loss ratio (VCLR); (c),TPC loss ratio (TPCLR); (d), ellagic acid loss ratio (EALR).
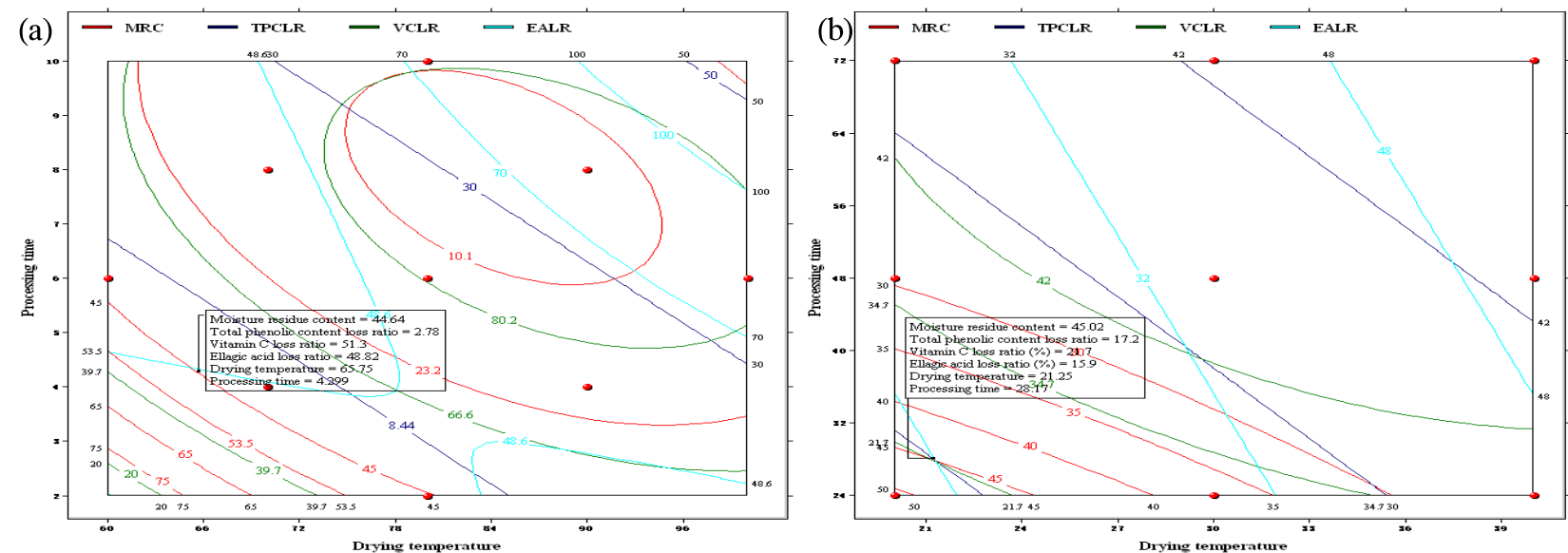

Fig. 5. Superimposed contour plots for semi-drying raspberries under (a) hot-air drying conditions and (b) cool-air drying conditions.

employed for producing semi-dried raspberries. The effects of temperature and processing time on moisture residue ratio (MRR), vitamin C loss ratio (VCLR), total phenolic content loss ratio (TPCLR), and ellagic acid loss ratio (EALR) were investigated. RSM was used in order to optimize the drying processes so as to minimize the losses of functional compounds and to improve fruit quality.
Effects of hot-air drying process on raspberries

Table 1 shows that the highest MRR (80.22\%) for hot-air drying was obtained at $60^{\circ} \mathrm{C}$ for $6 \mathrm{hr}$, while the lowest MRR $(25.29 \%)$ was observed at $80^{\circ} \mathrm{C}$ for $10 \mathrm{hr}$. Table 1 also indicates that the highest temperature $\left(100^{\circ} \mathrm{C}\right)$ used in this test led to the highest TPLCR (47.18\%) and VCLR (90.89\%). However, the highest EALR (61.63\%) was observed in test 
8 at $80^{\circ} \mathrm{C}$, using the longest processing time $(10 \mathrm{hr})$ in the CCD matrices.

ANOVA results in Table 2 suggest that hot-air fitted models for MRR, TPCLR, VCLR, and EALR were significant ( $\mathrm{p}<0.05$ ), with $\mathrm{R}^{2}$ values of $0.9222,0.8557,0.9508$, and 0.7912 , respectively, indicate good fitness of the selected second order polynomial model to the data. Table 2 also reveals that the process variables of both drying temperature and processing time proved significant $(\mathrm{p}<0.05)$ on $M R R$, TPCLR, and VCLR; however, EALR was only significantly influenced by processing time. Stationary points for the fitted models for MRR and EALR were saddle points, while stationary points for TPCLR and VCLR were maxima (Table 2). Fitted models for MRR, TPCLR, VCLR, and EALR are presented below :

$Y_{H A-M R R}=49.64-13.71^{*}$ temp $-10.12^{*}$ time $+1.03^{*}$ temp ${ }^{2}-1.77^{*}$ temp ${ }^{*}$ time $+0.30^{*}$ time $Y_{H A-T P C L R}=33.09+10.25^{*}$ temp $+8.40^{*}$ time $-3.48^{*}$ temp $^{2}+1.07^{*}$ temp $^{*}$ time $-3.66^{*}$ time $^{2}$ $Y_{H A-V C L R}=77.11+11.83^{*}$ temp $+10.45^{*}$ time $-3.41^{*}$ temp $^{2}+1.12^{*}$ temp ${ }^{*}$ time $-4.94^{*}$ time $^{2}$ $Y_{H A-E A L R}=38.69+5.46^{*}$ temp $+11.99^{*}$ time $+0.58^{*} t e m p^{2}-2.37^{*}$ temp ${ }^{*}$ time $-2.31^{*}$ time $^{2}$
Based on the fitted models, three-dimensional surface plots for MRR, TPCLR, VCLR, and EALR under hot-air drying conditions were constructed. Fig. 3(a) shows that MRR is linearly dependent on both processing time and drying temperature, decreasing from 100 to $0 \%$. Surface plots for VCLR and TPCLR in Fig. 3(b) and (c) show good quadratic effects, and with the increase of processing time and drying temperature, VCLR and TPCLR increase. Fig. 3(b) demonstrates that high temperature treatment leads to tremendous decrease (up to 80\%) in ascorbic acid content, and similar results were reported in previously studies (25-27). Gregory (19) has attempted to provide a rational explanation, proposing that the substantial loss of ascorbic acid during hot-air treatment is induced by the heat-mediated oxidation of ascorbic acid to dehydroascorbic acid, followed by hydrolysis to 2,3-diketogulonic acid and further polymerization to form nutritionally inactive products. However, unlike VCLR, TPCLR is limited to $40 \%$, as shown in Fig. 3(c). Dewanto et al. (28) reported that TPC does not change

Table 1. Central composite design (CCD) matrix for moisture residue content (MRR), vitamin C loss ratio (VCLR), total phenolic content loss ratio (TPCLR), and ellagic acid loss ratio (EALR) for semi-dried raspberries under hot-air drying conditions

\begin{tabular}{|c|c|c|c|c|c|c|}
\hline Test runs & Temp $\left({ }^{\circ} \mathrm{C}\right)$ & Time (h) & MRR (\%) & $\operatorname{VCLR}(\%)$ & TPCLR (\%) & EALR $(\%)$ \\
\hline 1 & $70(-1)^{\mathrm{a}}$ & $4(-1)$ & 66.34 & 56.99 & 5.88 & 11.41 \\
\hline 2 & $70(-1)$ & $8(+1)$ & 58.92 & 65.83 & 14.64 & 31.07 \\
\hline 3 & $90(+1)$ & $4(-1)$ & 41.87 & 74.17 & 25.41 & 42.37 \\
\hline 4 & $90(+1)$ & $8(+1)$ & 27.37 & 87.93 & 38.46 & 52.57 \\
\hline 5 & $60(-2)$ & $6(0)$ & 80.22 & 39.58 & 7.38 & 41.46 \\
\hline 6 & $100(+2)$ & $6(0)$ & 25.95 & 90.89 & 47.18 & 47.97 \\
\hline 7 & $80(0)$ & $2(-2)$ & 75.06 & 33.43 & 2.85 & 4.65 \\
\hline 8 & $80(0)$ & $10(+2)$ & 25.29 & 84.84 & 42.37 & 61.63 \\
\hline 9 & $80(0)$ & $6(0)$ & 57.00 & 80.49 & 36.10 & 44.36 \\
\hline 10 & $80(0)$ & $6(0)$ & 43.23 & 79.91 & 41.32 & 43.66 \\
\hline 11 & $80(0)$ & $6(0)$ & 53.60 & 80.40 & 39.22 & 40.85 \\
\hline 12 & $80(0)$ & $6(0)$ & 47.83 & 74.48 & 41.46 & 42.25 \\
\hline 13 & $80(0)$ & $6(0)$ & 42.63 & 79.34 & 43.99 & 38.73 \\
\hline
\end{tabular}

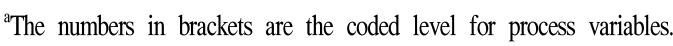

Table 2.Analysis of variance (ANOVA) results for moisture residue content (MRR), vitamin C loss ratio (VCLR), total phenolic content loss ratio (TPCLR), and ellagic acid loss ratio (EALR) for semi-dried raspberries under hot-air conditions

\begin{tabular}{ccccccccc}
\hline & Model & $\mathrm{R}^{2}$ & TEMP & TIME & TEMP*TEMP & TEMP*TIME & TIME*TIME & Stationary point \\
\hline MRR & $16.59^{* *}$ & 0.9222 & $-13.71^{* *}$ & $-10.12^{* *}$ & 1.03 & -1.77 & 0.30 & Saddle Point \\
VCR & $27.03^{* *}$ & 0.9508 & $11.83^{* *}$ & $10.45^{* *}$ & $-3.41^{* *}$ & $1.23^{* *}$ & $-4.94^{* *}$ & Maximum \\
TPCLR & $8.3^{* *}$ & 0.8557 & $10.25^{* *}$ & $8.4^{* *}$ & $-3.48^{*}$ & 1.07 & $-4.65^{* *}$ & Maximum \\
EALR & $5.3^{* *}$ & 0.7912 & $5.46^{*}$ & $11.99^{* *}$ & 0.58 & -2.365 & -2.31 & Saddle Point \\
\hline
\end{tabular}

${ }^{* * *}$ represents high significance with $\mathrm{p}<0.001 ;{ }^{* *}$ represents significance with $0.001 \leq \mathrm{p}<0.05$; ${ }^{*}$ represents less significance with $0.05 \leq \mathrm{p}<0.1$. 
significantly during thermal processing of fruits, and rather, thermal processing could enhance nutritional values by releasing bio-accessible compounds. Chism and Haard (29) assumed that TPC of fruits and vegetables is usually primarily contained in the vacuoles, and that thermal processes might accelerate the release of phenolic compounds as a result of the breakdown of cellular constituents. This explanation might account for the limited loss of phenolic acids under hot-air drying conditions. In addition, it is also noticed that EALR increases linearly with heating temperature and processing time, reaching over $60 \%$. Judging from the angle of the surface plot in Fig. 3(d), and processing time affects EALR more significantly.

\section{Effects of cool-air drying processes on raspberries}

The results for MRR, TPCLR, VCLR, and EALR for cool-air drying are presented in Table 3 . The temperature for cool-air drying ranged from 20 to $40^{\circ} \mathrm{C}$, and while processing time ranged from 22 to $66 \mathrm{hr}$. Raspberry samples processed at $20^{\circ} \mathrm{C}$ for $22 \mathrm{hr}$ received the highest MRR (86.52\%), and the lowest TPCLR (17.16\%), VCLR (27.36\%), and EALR (32.63\%). The highest TPCLR $(70.73 \%)$ and the lowest MRR $(36.83 \%)$ were detected in test 4 , at $40^{\circ} \mathrm{C}$ for $6 \mathrm{hr}$, and the highest VCLR $(60.54 \%)$ and EALR were found in test 8 , at $30^{\circ} \mathrm{C}$ for $66 \mathrm{hr}$, which was the longest time tested for cool-air drying.

ANOVA results in Table 4 show that the fitted models for MRR and TPCLR are highly significant $(\mathrm{p}<0.001)$, while high $\mathrm{R}^{2}$ values of 0.9796 and 0.9882 , respectively, indicate a good fit to the data and reliability for further prediction. VCLR and EALR models are also highly significant $(\mathrm{p}<0.05)$, with $R^{2}$ values of 0.9141 and 0.8119 , respectively, indicating a good fit. The fitted models for cool-air drying are presented as follows :

$Y_{C A-M R R}=62.48-11.45^{*}$ temp $-12.71^{*}$ time $-5.98^{*}$ temp ${ }^{2}+0.16^{*}$ temp $p^{*}$ time $+4.25^{*} t i m e^{2}$ $Y_{C A-T P C L R}=52.10+7.40^{*}$ temp $+20.91 *$ time $-1.98^{*}$ temp ${ }^{2}+4.79 *$ temp $*$ time $-12.40^{*}$ time $^{2}$ $Y_{C 4-V C L R}=47.17+2.47^{*}$ temp $+12.95^{*}$ time $-3.84^{*} t e m p^{2}-0.02 * t e m p^{*}$ time $-4.60^{*} t_{t i m e}{ }^{2}$ $Y_{C A-E A L R}=52.31+7.86^{*}$ temp $+9.44^{*}$ time $+4.25^{*}$ temp ${ }^{2}-2.50^{*}$ temp*time $-3.88^{*}$ time ${ }^{2}$

Table 3. Central composite design (CCD) matrix for moisture residue content (MRR), vitamin C loss ratio (VCLR), total phenolic content loss ratio (TPCLR), and ellagic acid loss ratio (EALR) for semi-dried raspberries under cool-air drying conditions and vacuum

\begin{tabular}{ccccccc}
\hline Test runs & Temp $\left({ }^{\circ} \mathrm{C}\right)$ & Time $(\mathrm{h})$ & MRR $(\%)$ & VCLR $(\%)$ & TPCLR (\%) & EALR (\%) \\
\hline 1 & $20(-1)^{\mathrm{a}}$ & $22(-1)$ & 86.52 & 27.36 & 17.16 & 32.63 \\
2 & $20(-1)$ & $66(+1)$ & 61.37 & 47.77 & 46.58 & 55.69 \\
3 & $40(+1)$ & $22(-1)$ & 61.35 & 33.53 & 22.17 & 49.16 \\
4 & $40(+1)$ & $66(+1)$ & 36.83 & 53.87 & 70.73 & 62.23 \\
5 & $20(-1)$ & $44(0)$ & 64.47 & 41.57 & 42.83 & 49.94 \\
6 & $40(+1)$ & $44(0)$ & 45.47 & 44.11 & 58.06 & 74.03 \\
7 & $30(0)$ & $22(-1)$ & 78.50 & 23.62 & 17.04 & 43.34 \\
8 & $30(0)$ & $66(+1)$ & 51.90 & 60.54 & 64.52 & 63.83 \\
9 & $30(0)$ & $44(0)$ & 65.93 & 48.18 & 50.35 & 49.07 \\
10 & $30(0)$ & $44(0)$ & 61.73 & 48.14 & 51.38 & 51.39 \\
11 & $30(0)$ & $44(0)$ & 62.64 & 48.77 & 52.48 & 50.17 \\
13 & $30(0)$ & $44(0)$ & 63.66 & 49.47 & 55.74 & 58.46 \\
\hline
\end{tabular}

${ }^{a}$ The numbers in brackets are the coded level for process variables.

Table 4. Analysis of variance (ANOVA) results for moisture residue content (MRR), vitamin C loss ratio (VCLR), total phenolic content loss ratio (TPCLR), and ellagic acid loss ratio (EALR) for semi-dried raspberries under cool-air conditions and vacuum

\begin{tabular}{ccccccccc}
\hline & Model & $\mathrm{R}^{2}$ & TEMP & TIME & TEMP*TEMP & TEMP*TIME & TIME*TIME & Stationary point \\
\hline MRR & $67.10^{* * *}$ & 0.9796 & $11.45^{* * *}$ & $12.71^{* * *}$ & $-5.98^{* *}$ & 0.16 & $4.25^{* *}$ & Saddle Point \\
VCLR & $14.90^{* *}$ & 0.9141 & 2.47 & $12.95^{* * *}$ & -3.83 & -0.02 & $-4.60^{*}$ & Maximum \\
TPCLR & $117.25^{* * *}$ & 0.9882 & $7.40^{* *}$ & $20.91^{* * *}$ & -1.98 & $4.79^{* *}$ & $-11.65^{* * *}$ & Maximum \\
EALR & $6.04^{* *}$ & 0.8119 & $7.86^{* *}$ & $9.44^{* *}$ & 4.52 & -2.5 & -3.88 & Saddle Point \\
\hline
\end{tabular}

\footnotetext{
${ }^{* * *}$ represents high significance with $\mathrm{p}<0.001 ;{ }^{* *}$ represents significance with $0.001 \leq \mathrm{p}<0.05$; ${ }^{*}$ represents less significance with $0.05 \leq \mathrm{p}<0.1$.
} 
Three-dimensional surface plots for MRR, TPCLR, VCLR, and EALR for cool-air drying are shown in Fig. 4(a) (d). Fig. 4(a) exhibits a good quadratic effect, and drying temperature and processing time show negative effects on MRR. MRR is reduced from $80 \%$ to $40 \%$ when the drying temperature is increased from 20 to $40^{\circ} \mathrm{C}$ and drying time is extended to $70 \mathrm{hr}$. According to ANOVA results in Table 4 , processing time is the only variable significantly affecting ascorbic acid reduction during the cool-air drying process, which is also demonstrated in Fig. 4(b). Fig. 4(c) and (d) show that TPCLR and EALR are high (more than $70 \%$ as predicted) when cool-air treatment is used. Recent studies $(30,31)$ suggest that this might be due to the hydrolysis, oxidation, and polymerization of phenolic compounds. It is also noteworthy that TPC loss was higher in cool-air dried raspberries than in hot-air dried ones, because low temperature treatment tends to preserve thermally sensitive compounds from decomposition in most circumstances. But Ding et al. (32) and Trejo-Gonzalez et al. (33) both referred a possible explanation that the temperature activated enzyme polyphenoloxidase (PPO) can induce oxidation and degradation of phenolic compounds. According to Concellón et al. (34) the optimal temperature for fruit PPO activity is in the range of $30-40^{\circ} \mathrm{C}$, which explains why cool-air drying under $40^{\circ} \mathrm{C}$ causes higher TPCLR in raspberry fruits than hot-air drying.

\section{Optimization of different drying processes for raspberries}

Optimization is an important method in the food industry for monitoring critical process variables and yielding high-quality products. Madamba et al. (35) reported that the application of optimization to drying processes could yield mathematical models, which could help minimize nutrient loss, a factor that directly correlates to the quality of food products. The main goal of this research was to semi-dry raspberries and to determine whether the best processing conditions are found through traditional hot-air processing or through the use of cool-air. Since only two process variables were involved in this study, the most effective approach could be the superimposed contour diagrams of different response variables. Fig. 5(a) and (b) show the superimposed contour plots for MRR, TPCLR, VCLR, and EALR, as affected by both drying temperature and processing time under hot-air and cool-air, respectively. The optimum conditions for drying of raspberry fruits were set at $45 \% \mathrm{MRR}$, with minimal values for TPCLR, VCLR, and EALR. With these parameters set, the optimal conditions for semi-drying raspberries with hot-air were found to be a drying temperature of $65.8^{\circ} \mathrm{C}$ and a processing time of $4.3 \mathrm{hr}$, at which VCLR, TPCLR, and EALR were predicted to be $51.3 \%, 2.8 \%$, and $48.8 \%$, respectively. Meanwhile, the optimal conditions for cool-air drying were calculated to be $21.3^{\circ} \mathrm{C}$ and $28.2 \mathrm{hr}$, with VCLR, TPCLR, and EALR values of $21.7 \%, 17.2 \%$, and $15.9 \%$, respectively.

\section{요 약}

ANOVA 분석을 통해 건조온도와 건조시간이 열풍건조 와 냉풍건조의 중요변수임을 알 수 있었으며 복분자의 반건 조를 위해서는 열풍건조의 경우 $65.8^{\circ} \mathrm{C}, 4.3$ 시간이 적당하 였고 냉풍건조의 경우 비슷한 정도의 건조수분함량까지 28.2시간이 걸렸다. 그러나 건조온도가 높아지면 vitamin $\mathrm{C}$ 와 ellagic acid의 함량이 줄어드는 등 품질적 열화가 심하 게 나타났다. 또한 생리활성물질들은 냉풍건조에서 전반적 으로 더 잘 보존 되었으며 총폴리페놀의 함량에서는 더욱 그러하였다. 따라서 냉풍건조방법은 고품질의 반건조 복분 자 제조에 적합한 건조방법이며 최적 건조조건은 $21.3^{\circ} \mathrm{C}$, 28.2시간으로 나타났다.

\section{Acknowledgement}

This research was supported by Kyungpook National University Research Fund, 2011.

\section{References}

1. Ku CS, Mun SP (2008) Optimization of the extraction of anthocyanin from Bokbunja (Rubus coreanus Miq.) marc produced during traditional wine processing and characterization of the extracts. Biore Technol, 99, 8325-8330

2. Nohynek LJ, Alakomi HL, Kahkonen MP, Heinonen M, Helander KM, Oksman-Caldentey KM, Puupponen-Pimia RH (2006) Berry phenolics : antimicrobial properties and mechanisms of action against severe human pathogens. Nutr Cancer, 54, 18-32

3. Mullen W, Lean MEJ, Crozier A (2002) Rapid characterization of anthocyanins in red raspberry fruit by high-performance liquid chromatography coupled to single quadrupole mass spectrometry. J Chromatogr A, 966, 63-70

4. Deighton N, Brennan R, Finn C, Davies HV (2000) Antioxidant properties of domesticated and wild Rubus 
species. J Sci Food Agr, 80, 1307-1313

5. Ovaskainen ML, Torronen R, Koponen JM, Sinkko H, Hellstrom J, Reinivuo H, Mattila P (2008) Dietary intake and major food sources of polyphenols in Finnish adults. J Nutr, 138, 562-566

6. Haffner K, Rosenfeld HJ, Skrede G, Wang LX (2002) Quality of red raspberry Rubus idaeus L. cultivars after storage in controlled and normal atmospheres. Postharvest Biol Tec, 24, 279-289

7. de Ancos B, Ibanez E, Reglero G, Cano MP (2000) Frozen storage effects on anthocyanins and volatile compounds of raspberry fruit. J Agr Food Chem, 48, 873-879

8. Gould GW (1996) Methods for preservation and extension of shelf life. Int J Food Microbiol, 33, 51-64

9. Doymaz İ (2004) Pretreatment effect on sun drying of mulberry fruits (Morus alba L.). J Food Eng, 65, 205-209

10. Ertekin C, Yaldiz O (2004) Drying of eggplant and selection of a suitable thin layer drying model. J Food Eng, 63, 349-359

11. Ratti C (2001) Hot air and freeze-drying of high-value foods : a review. J Food Eng, 49, 311-319

12. Choi JH, Jeong JY, Han DJ, Choi YS, Kim HY, Lee MA, Lee ES, Paik HD, Kim CJ (2008) Effects of pork/beef levels and various casings on quality properties of semi-dried jerky. Meat Sci, 80, 278-286

13. Jeong JW, Seong JM, Park KJ, Lim JH (2007) Quality characteristics of semi dried red pepper (Capsicum annuum L.) using hot-air drying. Korean J Food Preserv, 14, 591-597

14. Karathanos VT, Belessiotis VG (1999) Application of a thin-layer equation to drying data of fresh and semi-dried fruits. J Agr Eng Res, 74, 355-361

15. Toor RK, Savage GP (2006) Effect of semi-drying on the antioxidant components of tomatoes. Food Chem, 94, 90-97

16. Banga JR, Balsa-Canto E, Moles CG, Alonso AA (2003) Improving food processing using modern optimization methods. Trends Food Sci Technol, 14, 131-144

17. Singleton VL, Orthofer R, Lamuela-Raventos RM (1999) Analysis of total phenols and other oxidation substrates and antioxidants by means of Folin-Ciocalteu reagent. Method Enzymol, 299, 152-178

18. Phillips KM, Tarrago-Trani MT, Gebhardt SE, Exler J, Patterson KY, Haytowitz DB, Pehrsson PR, Holden JM (2010) Stability of vitamin C in frozen raw fruit and vegetable homogenates. J Food Comp Anal, 23, 253-259
19. J.F. G (1996)Vitamins, Marcel Dekker, Inc, New York

20. Uddin MS, Hawlader MNA, Zhou LW (2001) Kinetics of ascorbic acid degradation in dried kiwifruits during storage. Dry Technol, 19, 437-446

21. Puupponen-Pimia R, Nohynek L, Hartmann-Schmidlin S, Kahkonen M, Heinonen M, Maatta-Riihinen K, Oksman-Caldentey KM (2005) Berry phenolics selectively inhibit the growth of intestinal pathogens. J Appl Microbiol, 98, 991-1000

22. Mejia-Meza EI, Yanez JA, Remsberg CM, Takemoto JK, Davies NM, Rasco B, Clary C (2010) Effect of dehydration on raspberries : polyphenol and anthocyanin retention, antioxidant capacity, and antiadipogenic activity. J Food Sci, 75, H5-H12

23. Nichenametla SN, Taruscio TG, Barney DL, Exon JH (2006) A review of the effects and mechanisms of polyphenolics in cancer. Crit Rev Food Sci, 46, 161-183

24. Hakkinen SH, Karenlampi SO, Mykkanen HM, Heinonen IM, Torronen AR (2000) Ellagic acid content in berries : influence of domestic processing and storage. Eur Food Res Technol, 212, 75-80

25. Burg P, Fraile $P$ (1995) Vitamin-C destruction during the cooking of a potato dish. Food Sci Technol-leb, 28, 506-514

26. Chang CH, Lin HY, Chang CY, Liu YC (2006) Comparisons on the antioxidant properties of fresh, freeze-dried and hot-air-dried tomatoes. J Food Eng, 77, 478-485

27. Murcia MA, Lopez-Ayerra B, Martinez-Tome M, Vera AM, Garcia-Carmona F (2000) Evolution of ascorbic acid and peroxidase during industrial processing of broccoli. J Sci Food Agr, 80, 1882-1886

28. Dewanto V, Wu XZ, Adom KK, Liu RH (2002) Thermal processing enhances the nutritional value of tomatoes by increasing total antioxidant activity. J Agr Food Chem, 50, 3010-3014

29. Owen R. Fennema (1996), Food Chem, Marcel Dekker, Inc., New York, USA, p 943-1011

30. Laine P, Kylli P, Heinonen M, Jouppila K (2008) Storage stability of microencapsulated cloudberry (Rubus chamaemorus) phenolics. J Agr Food Chem, 56, 11251-11261

31. Ngo T, Wrolstad RE, Zhao Y (2007) Color quality of Oregon strawberries - Impact of genotype, composition, and processing. J Food Sci, 72, C25-C32

32. Ding CK, Chachin K, Ueda Y, Imahori Y (1998) Purification and properties of polyphenol oxidase from 
loquat fruit. J Agr Food Chem, 46, 4144-4149

33. Trejo-Gonzalez A, Soto-Valdez H (1991) Partial characterization of polyphenoloxidase extracted from 'Anna' apple. J Am Soc Hortic Sci, 116, 672-675

34. Concellón Aa, Añón MaC, Chaves AR (2004) Characterization and changes in polyphenol oxidase from eggplant fruit (Solanum melongena L.) during storage at low temperature. Food Chem, 88, 17-24

35. Madamba PS (2002) The response surface methodology $:$ an application to optimize dehydration operations of selected agricultural crops. Lebensm-Wiss Technol, 35, 584-592 